\title{
Aromatase expression in Xenopus oocytes: a three cell-type model for the ovarian estradiol synthesis
}

\author{
M Gohin ${ }^{1,2}$, P Bodinier $^{2}$, A Fostier $^{2}, \mathrm{~J} \mathrm{Bobe}^{2}$ and F Chesnel ${ }^{1}$ \\ ${ }^{1}$ CNRS/IGDR (UMR 6061), IFR140 GFAS, Université de Rennes I, 2 Avenue du Pr. Léon Bernard, 35043 Rennes Cedex, France \\ ${ }^{2}$ Institut National de la Recherche Agronomique, INRA, SCRIBE UR1037, IFR140 GFAS, Campus de Beaulieu, 35000 Rennes Cedex, France \\ (Correspondence should be addressed to F Chesnel; Email: franck.chesnel@univ-rennes1.fr; J Bobe; Email: julien.bobe@rennes.inra.fr)
}

\begin{abstract}
In contrast to the classical model describing the synthesis of androgens and estrogens as restricted to somatic cells, a previous study demonstrated that Xenopus laevis oocytes participate in androgen synthesis. The objective of our study was to determine whether Xenopus oocytes are also involved in estrogen synthesis. More precisely, we analyzed aromatase expression by in situ hybridization and RT-QPCR and measured aromatase activity. Aromatase, the enzyme responsible for estrogen synthesis, appears to be expressed and active not only in the follicular cells but also in the vitellogenic oocytes. During late oogenesis, aromatase oocyte expression and activity decreased concomitantly with the trend observed in surrounding follicular layers. In order to investigate the role of estradiol- $17 \beta\left(E_{2}\right)$, we studied its effect on oocyte meiotic resumption. It appears that, as in Rana pipiens, $\mathrm{E}_{2}$ inhibited the follicle-enclosed maturation of Xenopus oocytes, likely through inhibition of $\mathrm{LH}$-induced maturation-inducing steroid synthesis. In addition, $\mathrm{E}_{2}$ exerted a slight enhancing action on denuded oocyte maturation whose biological significance remains unclear. Together, our results demonstrate that Xenopus oocyte significantly participates in ovarian $\mathrm{E}_{2}$ synthesis and this may be a common feature of vitellogenic vertebrates.
\end{abstract}

Journal of Molecular Endocrinology (2011) 47, 241-250

\section{Introduction}

Estradiol-17 $\beta\left(\mathrm{E}_{2}\right)$ is known to have pleiotropic effects and important roles in female reproductive function in vertebrates, and characterizing the regulation and function of $\mathrm{E}_{2}$ synthesis during ovarian follicular growth is a major challenge in reproductive biology. Throughout oogenesis, $\mathrm{E}_{2}$ is synthesized by ovarian follicles and secreted into the blood. Growth and development of Xenopus laevis follicles are accompanied by shifts in steroidogenic abilities, with $\mathrm{E}_{2}$ produced by medium-sized follicles and androgen and progesterone secreted by large, postvitellogenic follicles (Fortune 1983). In non-mammalian vertebrates, the best-known endocrine effect of $E_{2}$ is the stimulation of yolk synthesis through hepatic vitellogenins synthesis and secretion into blood circulation. Circulating vitellogenins are taken up by the oocyte leading to oocyte yolk accumulation and growth (Rasar \& Hammes 2006). Yolk will provide nutritional reserves necessary for embryo development. More recently, $\mathrm{E}_{2}$ was also shown to enhance progesterone-induced ovulation, possibly through a stimulatory effect on gonadotropin synthesis (Ogawa et al. 2011). In addition to $\mathrm{E}_{2}$ endocrine effects, $\mathrm{E}_{2}$ may have autocrine and/or paracrine effects, as $\mathrm{E}_{2}$ inhibits follicle-enclosed oocyte maturation through inhibition of maturation-inducing steroid (MIS) synthesizing enzymes in vitellogenic species such as Rana pipiens (Schuetz 1972, Spiegel et al. 1978, Lin \& Schuetz 1983, 1985) or Oncorhynchus mykiss (Jalabert et al. 1984). This steroid may also activate transcription of particular genes within the oocyte that would play a role in oocyte development, such as IGFBP3, the expression of which has been shown to be positively regulated by $\mathrm{E}_{2}$ in trout oocytes (Kamangar et al. 2006).

$\mathrm{E}_{2}$ is synthesized by the cytochrome $\mathrm{P} 450$ aromatase enzyme that converts androstenedione and testosterone into estrone (E1) and $\mathrm{E}_{2}$ respectively. In Xenopus, two variants are expressed in the gonads and a third variant is expressed in the brain (Iwabuchi et al. 2007). As for mammals (Gore-Langton \& Amstrong 1988) and fish (Nagahama et al. 1995), a two cell-type model has been proposed to describe amphibian $\mathrm{E}_{2}$ synthesis by the whole follicle (Kwon \& Ahn 1994, Ahn et al. 1999). According to this classical model, theca cells provide androgens to granulosa cells that, in turn, aromatize androgens into estrogens. Nevertheless, in Xenopus laevis, some steroidogenic activity had been previously reported in oocytes (Yang et al. 2003). Besides oocyte ability to metabolize exogenous steroid precursors (Reynhout \& Smith 1973, Sanyal et al. 1973, Fouchet et al. 1975, Thibier-Fouchet et al. 1976), 17-hydroxylase/ 17,20-lyase (Cyp17) appeared to be expressed only by

DOI: 10.1530/JME-11-0080 Online version via http://www.endocrinology-journals.org 
the oocyte in Xenopus ovary (Yang et al. 2003). Cyp17 is a key enzyme mediating androgen production, suggesting that Xenopus oocytes participate in synthesis of estrogen precursors. Moreover, Xenopus oocytes were shown to be required for $\mathrm{E}_{2}$ production by growing stage IV follicles in response to gonadotropin (Sretarugsa \& Wallace 1997). Thus, the objective of this study was to determine oocyte contribution to $\mathrm{E}_{2}$ synthesis in Xenopus laevis by characterizing the expression and activity of the estrogenic enzyme, the aromatase. Moreover, contradictory results have been reported concerning $\mathrm{E}_{2}$ effects on progesteroneinduced oocyte maturation in Xenopus laevis. Some authors have shown less potentiating effects after $E_{2}$ pretreatment on in vitro denuded oocyte maturation (Hanocq-Quertier \& Baltus 1981, Pickford \& Morris 1999), while antagonistic effects have also been reported (Baulieu et al. 1978). Therefore, we finally investigated the effect of $\mathrm{E}_{2}$ on meiotic resumption of either follicle-enclosed or denuded oocytes.

\section{Materials and Methods}

\section{Animals and tissue collections}

Investigation and animal care were conducted in compliance with French and European regulations on the care and use of laboratory animals. Xenopus laevis ovarian pieces were surgically removed from anesthetized adult females, purchased from NASCO (Fort Atkinson, WI, USA). Stage IV (st IV, 800 $\mu \mathrm{m}$ diameter (Dumont 1972)), and stage VI (st VI PI, $>1200 \mu \mathrm{m}$ diameter, in prophase I of meiosis) ovarian follicles were manually isolated from ovarian pieces of each female in modified OR2 buffer $(83 \mathrm{mM} \mathrm{NaCl}, 2.5 \mathrm{mM}$ $\mathrm{KCl}, 1 \mathrm{mM} \mathrm{CaCl}_{2}, 1 \mathrm{mM} \mathrm{MgCl}_{2}$, and $5 \mathrm{mM}$ HEPES, $\mathrm{pH}$ 7•4). Corresponding oocytes and follicular cells were manually isolated from ovarian pieces or from individual follicles after incubation in calcium-free OR2 buffer supplemented with collagenase (type 1A, Sigma-Aldrich; final concentration $=275 \mathrm{IU} / \mathrm{ml})$. Ovarian tissues were frozen in liquid nitrogen and stored at $-80^{\circ} \mathrm{C}$ until use. For in situ hybridization, ovarian tissues were fixed in Dietrich's fixative $(10 \%$ formaldehyde $40 \%, 29 \%$ ethanol $95 \%$, and $2 \%$ glacial acetic acid) overnight at $4{ }^{\circ} \mathrm{C}$, rinsed in diethylpyrocarbonate (DEPC) water five times for $10 \mathrm{~min}$, and then stored at $4{ }^{\circ} \mathrm{C}$ in $50 \%$ ethanol until paraffin embedding.

\section{In vitro oocyte maturation}

Follicle-enclosed and denuded oocytes were incubated for $15 \mathrm{~h}$ at $20^{\circ} \mathrm{C}$ in modified OR2 buffer supplemented with $40 \mathrm{IU} / \mathrm{ml}$ human chorionic gonadotropin (hCG; Organon, Puteaux, France; LaMarca et al. 1985) or with $0 \cdot 1-1 \mu \mathrm{M}$ progesterone (Baulieu et al. 1978). $\mathrm{E}_{2}(1 \mu \mathrm{M}$ final concentration; Steraloids, Newport, RI, USA) was added simultaneously. Approximately $30 \mathrm{pg} \mathrm{E}_{2}$ diluted in PBS with $1 \mathrm{mg} / \mathrm{ml} \mathrm{BSA}$ and $10 \%$ ethanol were injected directly into stage VI PI oocytes. Oocytes injected with equivalent volume of steroid vehicle ( $15 \mathrm{nl}$ PBS containing $10 \%$ ethanol and BSA $1 \mathrm{mg} / \mathrm{ml}$ ) were used as control. After incubation, germinal vesicle breakdown (GVBD), which reflects meiosis resumption, was assessed by direct observation under a stereomicroscope of the appearance of a white spot on the animal pole of the follicle-enclosed or denuded oocytes.

\section{In situ hybridization}

In situ hybridization was performed as described previously (Mourot et al. 2006, Vizziano et al. 2007). In brief, ovarian tissue was processed in a citadel 1000 tissue processor (Shandon, Pittsburgh, PA, USA). Dehydrated tissues were embedded in paraffin in plastic molds using a HistoEmbedder (TBS88; Medite, Burgdorf, Germany). In situ hybridization was performed using the In situ Pro, Intavis AG robotic station on $10 \mu \mathrm{m}$ sections. P450-arom sense and antisense probes were synthesized from Xenopus cDNA clone (BC079750.1) using Riboprobe Combination System (Promega). PCR products were generated using M13 reverse and forward primers (CCCAGTCACGACGTTGTAAAACGA/AGCGGATAACAATTTCACACAGGA) and were incubated (300 ng) for $2 \mathrm{~h}$ at $37^{\circ} \mathrm{C}$ with sense (SP6) or antisense (T7) primers in transcription buffer as described previously (Gohin et al. 2011). Probe concentration and quality were assessed using nanodrop ND-1000 spectrophotometer (NanoDrop, Wilmington, DE, USA). Hybridization specificity was controlled by comparing signals obtained with the antisense and the sense probes on adjacent sections. Mounted sections were photographed with an ECLIPSE 90i microscope and NIS Advanced Research Software (Nikon Instruments, Amstelveen, The Netherlands).

\section{P450-arom mRNA synthesis and injection}

The cDNA corresponding to Xenopus laevis p450-arom open reading frame (ORF; GenBank accession number: NM_001085653) was subcloned into the pCS2+ expression vector (Rupp et al. 1994, Turner \& Weintraub 1994). Capped p450-arom RNA was prepared after NotI linearization using mMessage mMachine Kit (Ambion) and purified according to the manufacturer's instructions. In vitro transcribed capped p450-arom $\mathrm{RNA}$ was injected into stage VI prophase I denuded oocytes $(\sim 15 \mathrm{nl}$ of a $1 \mu \mathrm{g} / \mu \mathrm{l}$ solution). Microinjected oocytes were then incubated at room temperature $\left(20^{\circ} \mathrm{C}\right)$ for $12-24 \mathrm{~h}$ in modified OR2 buffer before any treatment or freezing. 


\section{RNA purification, $R T$, and real-time quantitative PCR}

Total RNA was extracted from Xenopus follicles or denuded oocytes using Tri-Reagent (Molecular Research Center, Cincinnati, OH, USA) according to the manufacturer's instructions. Total RNA was repurified using a Nucleospin RNA II kit (Macherey Nagel, Germany) and $2 \mu \mathrm{g}$ RNA were reverse transcribed using 200 units Moloney murine leukemia virus reverse transcriptase (Promega) and $1 \mu \mathrm{g}$ random hexamers (Promega) in a master mix containing $2 \mathrm{mM}$ dNTPs, $50 \mathrm{mM}$ Tris- $\mathrm{HCl}, 75 \mathrm{mM} \mathrm{KCl}, 3 \mathrm{mM} \mathrm{MgCl}_{2}, 10 \mathrm{mM}$

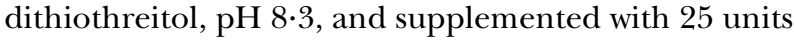
of RNase inhibitor (RNasin, Promega) as described previously (Bobe et al. 2006). Control reactions were run without enzyme and used as negative controls in the real-time PCR study.

QPCR was carried out using a real-time PCR Step One Plus system (Applied Biosystems, Foster City, CA, USA). RT products were diluted to $1 / 25$. Triplicates were run for each RT product. Real-time PCR was performed using a kit provided with a SYBR Green fluorophore (Fast SYBR Green Master Mix, Applied Biosystems). Primer concentrations were $200 \mathrm{nM}$ for $18 \mathrm{~S}$ and $600 \mathrm{nM}$ for p450-arom, star, $\mathrm{E}_{2}$ receptor 1 (esr1a and esr $1 b)$. A pool of reverse-transcribed RNA was serially diluted and used to calculate a standard curve for each gene. $18 \mathrm{~S}$ was used as an internal standard to normalize QPCR signal. Amplification cycle and fusion curve protocol followed the same steps as described previously (Gohin et al. 2010). The primers used are presented in Table 1.

\section{Aromatase activity assay}

A tritiated water release assay was used to measure aromatase activity using androstenedione as a precursor. One hundred stage IV and 50 stage VI PI follicles, denuded oocytes, and corresponding follicular layers were homogenized in $1.5 \mathrm{ml}$ phosphate buffer $(20 \mathrm{mM}$ $\mathrm{Na}_{2} \mathrm{HPO}_{4}, 0 \cdot 2 \mathrm{M} \mathrm{NaCl}, 0 \cdot 15 \mathrm{M} \mathrm{KCl}, 0 \cdot 25 \mathrm{M}$ saccharose, $5 \mathrm{mM}$ dithiothreitol, and $1 \mathrm{mM} 4$-(2-aminoethyl) benzenesulfonyl fluoride hydrochloride (Sigma-Aldrich), $\mathrm{pH}$ 7.55) using an ultra-turrax. Extracts were centrifuged at $12800 \mathrm{~g}$ for $15 \mathrm{~min}$ at $4{ }^{\circ} \mathrm{C}$ and the assay was performed using the supernatants.

The tritiated water release assay for aromatase activity determination was adapted from previous studies (Gore-Langton \& Dorrington 1981, Monod et al. 1993) using $450 \mu \mathrm{l}$ Xenopus extracts in duplicates adjusted to $500 \mu \mathrm{l}$ after adding the cofactor NADPH ( $1 \mathrm{mM}$, Sigma-Aldrich) and $1 \beta{ }^{3} \mathrm{H}$-androstenedione (s.a. $=0.87 \mathrm{TBq} / \mathrm{mmol}$, PerkinElmer, Boston, MA, USA; $19 \mathrm{kBq}$ to a final concentration of $50 \mathrm{nM}$ ). The reaction was performed at $16^{\circ} \mathrm{C}$ under agitation for $20 \mathrm{~h}$ and terminated by adding $50 \mu \mathrm{l} 3 \mathrm{M}$ trichloroacetic acid. After adding $450 \mu \mathrm{l}$ water, samples were centrifuged $\left(3500 \mathrm{~g}, 15 \mathrm{~min}, 4{ }^{\circ} \mathrm{C}\right)$. Supernatants $(700 \mu \mathrm{l})$ were transferred to $5 \mathrm{ml}$ glass tubes containing a charcoal pellet $(50 \mathrm{mg} /$ tube). Tubes were shaken for $7 \mathrm{~h}$ at $4{ }^{\circ} \mathrm{C}$ and then centrifuged $\left(3500 \mathrm{~g}, 15 \mathrm{~min}, 4^{\circ} \mathrm{C}\right)$. Duplicates of $400 \mu \mathrm{l}$ supernatants were mixed with $4 \mathrm{ml}$ liquid scintillation fluid (Pico-Fluor 40, PerkinElmer) for radioactivity counting for $10 \mathrm{~min}$.

\section{Steroid extraction}

One hundred stage IV and 50 stage VI PI denuded oocytes were homogenized in $1 \mathrm{ml}$ phosphate buffer. A tracer quantity of tritiated $\mathrm{E}_{2}\left(2,4,6,7{ }^{3} \mathrm{H}-\mathrm{E}_{2}\right.$ Amersham, GE Healthcare Europe Gmbh, Saclay, France; s.a. $=3.26 \mathrm{TBq} / \mathrm{mmol} ; 4000$ d.p.m. in $100 \mu \mathrm{l}$ buffer) was added to estimate steroid recovery. Homogenates were placed in $15 \mathrm{ml}$ glass tubes, supplemented with $5 \mathrm{ml}$ of $100 \%$ ethanol, and vortexed. After centrifugation at $3500 \mathrm{~g}$ for $15 \mathrm{~min}$ at $4{ }^{\circ} \mathrm{C}$, supernatants were collected and placed into $10 \mathrm{ml}$ glass tubes. Ethanol was evaporated at $50{ }^{\circ} \mathrm{C}$ under air and the aqueous phases were extracted three times with $5 \mathrm{ml}$ dichloromethane. After evaporation of the organic phase under air, dry residues were stored overnight at $-20^{\circ} \mathrm{C}$. $\mathrm{E}_{2}$ was further purified by a solvent partition into aqueous $\mathrm{NaOH}$ (Chatterton et al. 2004). Dry residues were dissolved in $1 \mathrm{ml}$ xylene and $\mathrm{E}_{2}$ was extracted twice with $1.5 \mathrm{ml} \mathrm{NaOH} 1 \mathrm{~N}$. The alkaline solutions were neutralized with $0.8 \mathrm{ml} \mathrm{HCl} 4 \mathrm{M}$ and $\mathrm{E}_{2}$ was re-extracted twice with $5 \mathrm{ml}$ dichloromethane. The final organic phases were evaporated and extracts were dissolved in $500 \mu \mathrm{l}$

Table 1 QPCR primer $5^{\prime}$-sequences-3' and corresponding GenBank accession number

\begin{tabular}{|c|c|c|c|}
\hline Gene & Accession number & Forward primer & Reverse primer \\
\hline Cyp19 & NM_001085653 & CTTCGGGGAGCAGTTTGTTA & CCTGTCATGCACAACCATCT \\
\hline Star & AF220437 & ACGGAGAACTGGTGGACAAC & CTCTGCTGCTTTCTCGTGTG \\
\hline Esr1a & NM_001089617.1 & TAGCTGGAACAGTGGACAGC & TCCAGTGGTTTTGTTGGGTAG \\
\hline Esr1b & NM_001089615 & TGGGGTAAACCCCTTATGTG & GTCCTCTTCAATTCCGATGC \\
\hline $18 S$ & X02995.1 & CGGAGGTTCGAAGACGATCA & TTCACGCCCTCTTGAACTCT \\
\hline
\end{tabular}


phosphate RIA buffer $\left(\mathrm{NaH}_{2} \mathrm{PO}_{4} 10 \mathrm{mM}, \mathrm{Na}_{2} \mathrm{HPO}_{4}\right.$ $10 \mathrm{mM}$, and $\mathrm{NaCl} 150 \mathrm{mM}, \mathrm{pH} 7 \cdot 25)$. One hundred microliters were used for radioactivity counting in $4 \mathrm{ml}$ Picofluor (PerkinElmer) for $10 \mathrm{~min}$ per sample to determine extraction yield and $100 \mu \mathrm{l}$ duplicates were used for $\mathrm{E}_{2}$ RIA.

\section{$E_{2}$ RIA}

$\mathrm{E}_{2}$ was measured by RIA as described previously (Fostier et al. 1982) using an anti- $\mathrm{E}_{2}$ rabbit antibody, 30000 d.p.m./tube of $2,4,6,7{ }^{3} \mathrm{H}-\mathrm{E}_{2}$ (s.a. $=3 \cdot 26 \mathrm{TBq}$ / mmol, PerkinElmer) as tracer and $5-3000 \mathrm{pg} /$ tube unlabeled $\mathrm{E}_{2}$ (Steraloids) as a reference.

\section{Statistical analysis}

Results are expressed as mean \pm s.E.M. Statistical analyses were performed using Statistica 7.0 Software (Statsoft, Tulsa, OK, USA). Differences among groups were analyzed using Mann-Whitney $U$ test or $\chi^{2}$ test for non-parametric samples. Differences between groups were considered significant when $P<0 \cdot 05$.

\section{Results}

\section{Aromatase is expressed in late vitellogenic oocytes and transcript levels dramatically decrease during late oogenesis in follicle-enclosed and denuded oocytes}

Aromatase transcript was detected in follicular cells of Xenopus vitellogenic follicles and appeared not homogenously distributed (Fig. 1A and $\mathrm{C}$ ). Under our experimental conditions, it was difficult to distinguish granulosa from theca cells. Aromatase transcript was also detected in the cytoplasm of previtellogenic stage I (100 $\mu \mathrm{m}$ diameter; Fig. 1E) to vitellogenic stage III and IV oocytes $(600 \mu \mathrm{m}$ diameter; Fig. 1A). Consistently with in situ hybridization results, aromatase was detected by RT-QPCR in Xenopus vitellogenic stage IV (st IV) oocytes (Fig. 2, left panel). During late vitellogenesis, the amount of aromatase transcript represented $25 \%$ of the signal in whole follicles. During oocyte maturation, aromatase expression dramatically decreased in both whole follicles and oocytes (Fig. 2, left panel: st VI MII).

In order to explore a possible contamination of oocyte extracts by follicle cell material, star expression was monitored under the same conditions in whole follicles and oocytes (Fig. 2, middle panel), as star has been described as expressed exclusively by the follicular cells in another non-mammalian vertebrate, the rainbow trout (Kusakabe et al. 2002, Gohin et al. 2011). Although star expression reached a very high level in Xenopus, no oocyte expression was detected significantly above

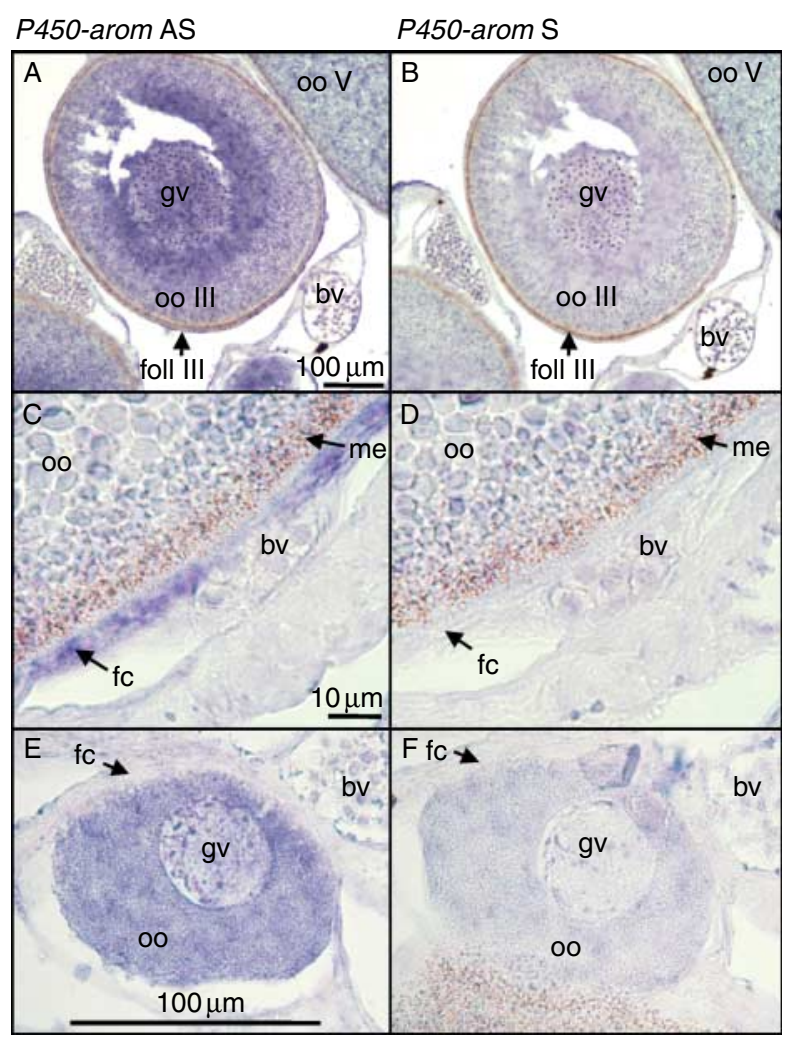

Figure 1 Localization of aromatase transcripts in Xenopus laevis ovaries. Xenopus p450-arom antisense (A, C, and E) and sense $(B, D$, and $F)$ probes were hybridized on adjacent ovarian sections. Xenopus $p 450$-arom transcripts were present in stage III oocytes (st III, >500 $\mu \mathrm{m}$ diameter) and in the corresponding follicular cells (st III foll) but not in the stage V oocytes (st V oo $>1000 \mu \mathrm{m}$ diameter). Gv, germinal vesicle; bv, blood vessel; me, melanosomes; fc, follicular cells.

background level (amplification from RT products without reverse transcriptase). As a control, 185 expression appeared stable among tissues (Fig. 2, right panel).

\section{Aromatase is active in oocytes and aromatase activity in follicle-enclosed and denuded oocytes dramatically decreases during late oogenesis}

To determine whether the corresponding protein was expressed in oocytes and because none of the custommade or commercially available antibodies that we tested cross-reacted with Xenopus aromatase, an enzyme activity assay was performed. From vitellogenic stage to postvitellogenic stage VI PI, a 70-fold decrease in aromatase activity occurred in the whole follicles (Fig. 3A). High levels of aromatase activity were also detected in Xenopus isolated follicular layers (follicular cells only). A significant activity was also detected in Xenopus late vitellogenic oocytes. In agreement with RT-QPCR data, Xenopus aromatase activity in the oocyte represented nearly $25 \%$ of the activity in the whole 

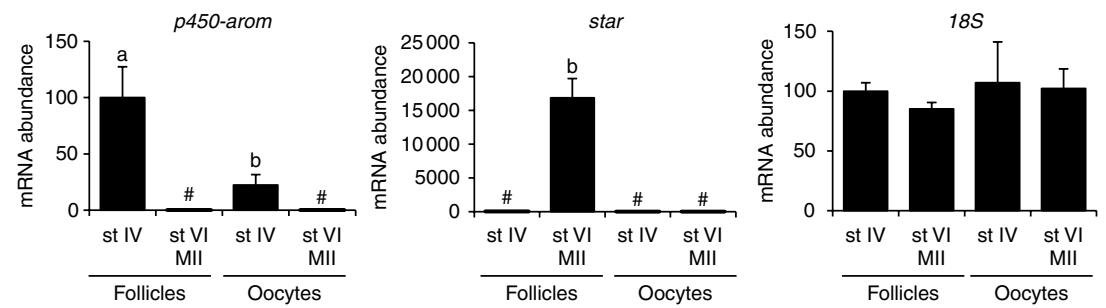

Figure 2 QPCR analysis of aromatase and star mRNA expression in whole Xenopus follicles and oocytes during late oogenesis. The mRNA levels of $p 450$-arom (left panel), star (middle panel), and $18 S$ (right panel) were monitored in whole follicles and denuded oocytes sampled during vitellogenic stage IV (st IV) and matured stage VI (st VI MII). For each sample, three separate RT reactions were carried out using three separate RNA samples originating from three different animals. Analysis of mRNA levels was standardized to levels of $18 S$ rRNA. Mean \pm S.E.M. are shown $(n=3)$. Different letters indicate significant differences (non-parametric Mann-Whitney $U$ test at $P<0.05$ ). "Not significantly different from background levels. For each gene, the mRNA abundance was arbitrarily set to 100 for stage IV follicles.

follicle. Finally, a low but significant level of aromatase activity $(1 \cdot 14 \pm 0 \cdot 24$ vs $0.53 \pm 0 \cdot 12 \mathrm{fmol} / 20 \mathrm{~h}$ in control) was measured in postvitellogenic, stage VI, follicles but no activity was detected in the corresponding denuded oocytes $(0.98 \pm 0 \cdot 2 \mathrm{fmol} / 20 \mathrm{~h}$; Fig. $3 \mathrm{~A})$. In order to demonstrate the specificity of the aromatase assay used in this study, we further showed that the activity measured by this assay was significantly increased in extracts of stage VI - prophase I arrested - oocytes previously $(12-24 \mathrm{~h})$ injected with $15 \mathrm{ng}$ in vitro synthesized and capped mRNA encoding $X l$ p450-arom ORF whereas no significant activity was detected in noninjected or water-injected oocytes (Fig. 3B).

\section{$E_{2}$ inhibits follicle-enclosed oocyte gonadotropin- induced maturation but facilitates progesterone- induced maturation of denuded oocytes}

In order to further understand $\mathrm{E}_{2}$ function in the oocyte, we measured $\mathrm{E}_{2}$ concentrations in Xenopus oocytes. $\mathrm{E}_{2}$ concentration in denuded oocytes (100 stage IV versus 50 stage VI PI oocytes from one female in duplicates) slightly decreased during late oogenesis from 7 to $5 \mathrm{pg}$ per oocyte. Thus, in stage IV $(800 \mu \mathrm{m}$ diameter and $0 \cdot 3 \mu \mathrm{l}$ volume $)$ and stage VI $(1250 \mu \mathrm{m}$ diameter and $1 \mu$ volume) oocytes, $\mathrm{E}_{2}$ concentration may be estimated to be 100 and $20 \mathrm{nM}$ respectively. $\mathrm{E}_{2}$ added simultaneously in culture medium dramatically inhibited Xenopus follicle-enclosed oocyte maturation induced by 40 units/ml hCG: only $8 \%$ of follicleenclosed oocytes resumed meiosis after incubation with hCG supplemented with $1 \mu \mathrm{M} \mathrm{E}_{2}$ while $65 \%$ matured in absence of $\mathrm{E}_{2}$ (Fig. 4A). To address the direct effect of $\mathrm{E}_{2}$ on the oocyte, we then checked its action on denuded oocytes (Fig. 4B and C). Female maturational competence was evaluated by the maturing response to $1 \mu \mathrm{M}$ progesterone after a $12 \mathrm{~h}$ treatment. Females in whom more than $50 \%$ of oocytes resumed meiosis were classified as highly responsive to progesterone stimulation, while females in whom $<50 \%$ of oocytes resumed meiosis were classified as poorly responsive. First, in neither group did $1 \mu \mathrm{M} \mathrm{E}_{2}$ inhibit resumption of meiosis of denuded oocytes contrarily to the results obtained with whole follicles. In contrast, it rather potentiated oocyte maturation induced by a subsaturating dose of progesterone $(0 \cdot 1 \mu \mathrm{M}$; Fig. $4 \mathrm{~B}$ and $\mathrm{C})$. At high progesterone concentration $(1 \mu \mathrm{M}=$ saturating
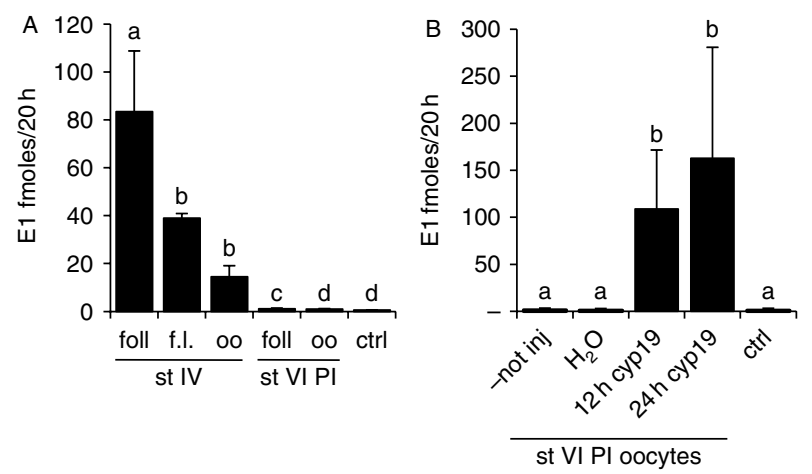

Figure 3 Aromatase activity in Xenopus whole follicles and denuded oocytes during late oogenesis. (A) Aromatase activity was measured by tritiated water release assay from whole follicles (foll) and denuded oocytes (oo) sampled at stage IV (st IV) and stage VI prior to meiosis resumption (st VI PI), and follicular layers (f.I.) from stage IV follicles. Activity is expressed as femtomoles of estrone (E1) synthesized over $20 \mathrm{~h}$ from three females in duplicates. (B) Aromatase activity in non-injected stage $\mathrm{VI}$ oocytes (not inj.), after injection of water $\left(\mathrm{H}_{2} \mathrm{O}\right)$, or after $12-24 \mathrm{~h}$ following the injection of $15 \mathrm{ng}$ p450-arom mRNA (12 h p450arom and $24 \mathrm{~h}$ 450-arom). Activity was measured in 50 prophase I stage VI oocytes from three females in duplicates. The controls (ctrl) correspond to phosphate buffer processed under the same conditions. Mean \pm S.E.M. are shown $(n=3)$. Different letters indicate significant differences (non-parametric Mann-Whitney $U$ test at $P<0.05)$. 


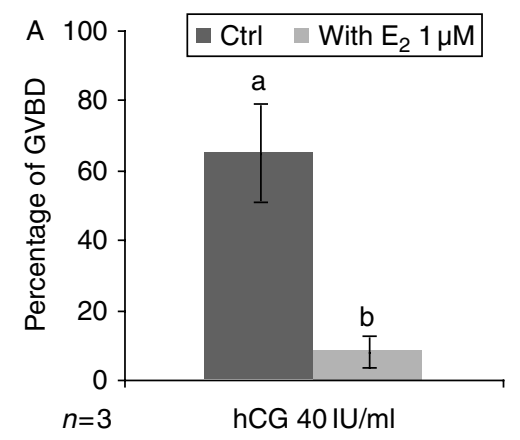

B Highly responsive females
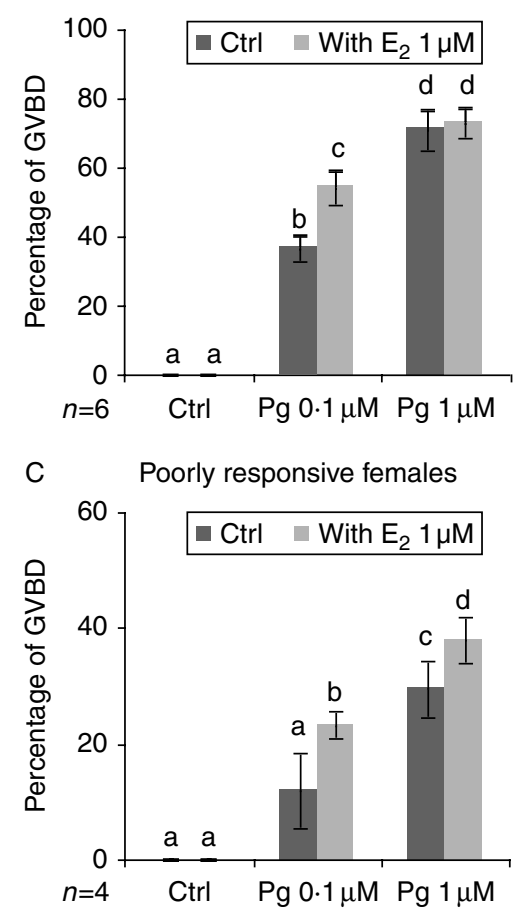

Figure 4 Effect of estradiol-17 $\beta\left(E_{2}\right)$ on resumption of meiosis of follicle-enclosed or denuded Xenopus oocytes induced by gonadotropin and progesterone respectively. Follicle-enclosed or denuded oocytes were incubated for $15 \mathrm{~h}$ in modified OR2 buffer supplemented with $40 \mathrm{IU} / \mathrm{ml}$ of human chorionic gonadotropin (hCG) (A) or with 0.1-1 $\mu \mathrm{M}$ progesterone (Pg; B and C). $1 \mu \mathrm{M} \mathrm{E}_{2}$ was added simultaneously. Females with more than $50 \%$ of maturing oocytes were classified as highly responsive to progesterone stimulation (B), while females with $<50 \%$ of maturing oocytes were classified as poorly responsive (C). After incubation, germinal vesicle breakdown (GVBD) was assessed by direct observation under a stereomicroscope of the appearance of a white spot on the animal pole. Mean \pm S.E.M. are shown. Different letters indicate significant differences (non-parametric $\chi^{2}$ test at $P<0.05$ ).

dose), $\mathrm{E}_{2}$ also exerted a slight but significant potentiating effect only in poorly responsive females (Fig. 4C). Finally, $\mathrm{E}_{2}$ alone did not stimulate oocyte maturation in any of the two groups (data not shown).

In order to confirm this slight but reproducible effect of $\mathrm{E}_{2}$ on oocyte maturation, $30 \mathrm{pg} \mathrm{E}_{2}$ (which represent around four times the physiological concentration in stage IV according to the results reported here and in previous studies (Fortune 1983)) were directly injected in 50 stage VI oocytes of three females. Oocytes were then stimulated with progesterone within $30 \mathrm{~min}$ following microinjection. No significant effect was detected on the final GVBD rates after $12 \mathrm{~h}$ incubation, but a potentiation was reproducibly observed during the time course of progesterone-induced oocyte maturation (Fig. 5) as sometimes evidenced in our $\mathrm{E}_{2}$ balneation experiments, especially with oocytes from low responsive females (data not shown).

\section{ESR1a and $b$ are expressed by the Xenopus oocyte}

In order to address whether $\mathrm{E}_{2}$ may exert its effect through ligand activation of the major estrogen receptor (ER $\alpha$; Esr1; two described isoforms in Xenopus: Esrla and b), we analyzed their mRNA expression by RT-QPCR in follicle-enclosed and denuded oocytes (Fig. 6). Both receptors were expressed in oocytes and their mRNA level, which represented $50 \%$ of the signal measured in whole follicles, remained stable at least throughout late oogenesis.

\section{Discussion}

Our results showed that in addition to the follicular cells, aromatase, the enzyme responsible of $\mathrm{E}_{2}$ synthesis is also expressed and active in Xenopus vitellogenic oocytes. Moreover, vitellogenic and postvitellogenic oocytes do express $\mathrm{ER} \alpha$ mRNA, suggesting that estrogens may participate in oocyte late development.

\section{Ovarian follicle $E_{2}$ synthesis, a three cell-type model}

In this study, aromatase expression and activity were detected in the follicular cells of Xenopus follicular cells as evidenced by in situ hybridization. Previous studies have already shown that aromatase is expressed by the follicular cells in the amphibian Rana rugosa during gonad development (Kato et al. 2004). However, our observations also demonstrate that follicular somatic cells are not the unique site of aromatase expression in Xenopus. Aromatase appears indeed expressed and active in vitellogenic oocytes. This observation leads to reconsider the two-cell cooperation model that has been proposed for amphibians (Ahn et al. 1999). Moreover, a significant level of aromatase activity was detected in Xenopus oocyte that corresponds to $25 \%$ of whole follicle aromatase activity. This steroidogenic activity is consistent with the mRNA expression that also corresponds to $25 \%$ of whole follicle expression. As a follicular control, we observed that star was exclusively 


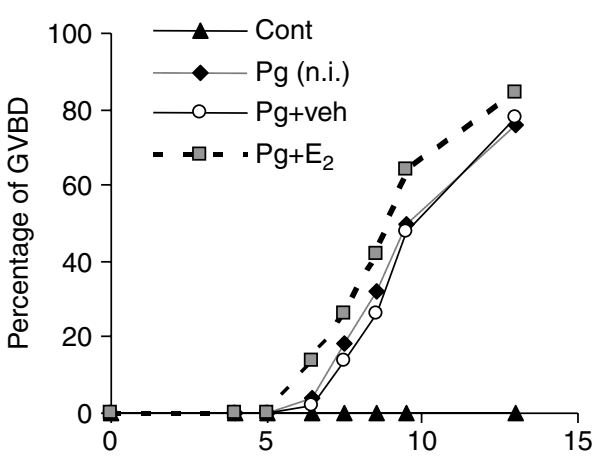

(h)

Figure 5 Effect of estradiol $\left(E_{2}\right)$ microinjection on progesteroneinduced resumption of meiosis of Xenopus denuded oocytes. Fifty stage VI prophase I oocytes were microinjected with $30 \mathrm{pg} \mathrm{E}_{2}$ or with vehicle buffer (veh.) and then incubated at room temperature in modified OR2 buffer completed with $1 \mu \mathrm{M}$ progesterone $(\mathrm{Pg}+$ $\mathrm{E}_{2}$ or $\mathrm{Pg}+$ veh. respectively), whereas 50 oocytes were only incubated with or without $1 \mu \mathrm{M}$ progesterone (Pg (n.i.) or cont. respectively). Germinal vesicle breakdown (GVBD) was assessed by direct observation under a stereomicroscope of the appearance of a white spot on the oocyte animal pole. Results are representative of three independent experiments.

expressed by the follicular cells. Star is involved in cholesterol shuttling to the inner mitochondrial membrane and is thus necessary for androgen and estrogen synthesis. As Cyp17 (Yang et al. 2003) and p450-arom are expressed by the oocyte, it suggests that a constant interaction exists between the somatic and the germinal follicular compartments for ovarian steroidogenesis to occur. Therefore, the contribution of the oocyte compartment to the overall follicular aromatase activity appears more important than initially believed. So far, aromatase expression in the oocyte of non-mammalian vertebrates was never clearly reported or discussed, even though a thorough analysis of existing literature revealed a positive protein signal in the oocyte of medaka (Park et al. 2008) and Rana rugosa (Kato et al. 2004), and we recently evidenced such an oocyte expression of cyp19a1a in rainbow trout (Gohin et al. 2011). In order to further investigate whether oocyte contribution to $\mathrm{E}_{2}$ synthesis is specific to a few vitellogenic species or, in contrast, a mechanism shared by evolutionary distant vertebrates, it would be interesting to perform such studies in other non-mammalian species.

The expression in the Xenopus oocyte of both Cyp17 (Yang et al. 2003) - the enzyme able to metabolize progestins into androgens - and p450-arom - the enzyme able to aromatize androgens - is consistent with an autonomous production of $\mathrm{E}_{2}$ by the oocyte. It is also very likely that steroid exchanges exist between oocyte and surrounding somatic follicular compartments, leading to difficulties to access the specific role of $\mathrm{E}_{2}$ synthesized by one compartment in comparison to the other. Moreover, it is also possible that oocytes modulate $\mathrm{E}_{2}$ production by the follicular somatic cells and reciprocally, as previously reported (Sretarugsa \& Wallace 1997). The regulation of aromatase expression and activity in the germinal compartment of the ovarian follicle during final oocyte maturation would be in favor of an active participation of $\mathrm{E}_{2}$ from oocyte origin in the intra-follicular dialog. Therefore, our findings and a previous report (Yang et al. 2003) clearly indicate that a third participant - the oocyte - has to be added to the two cell-type model of $\mathrm{E}_{2}$ synthesis in Xenopus. Nevertheless, determining the physiological role of $\mathrm{E}_{2}$ synthesized by the oocyte in comparison to the role of $\mathrm{E}_{2}$ of somatic origin is difficult to perform for technical reasons as local inhibition of oocyte aromatase within each compartment of the whole follicle cannot be performed by microinjection or use of aromatase inhibitors.

\section{Modulation of Xenopus oocyte maturation by $\mathrm{E}_{2}$}

Oocyte aromatase expression and activity decreased during late oogenesis concomitantly with a decrease in aromatase expression and activity in the whole follicle
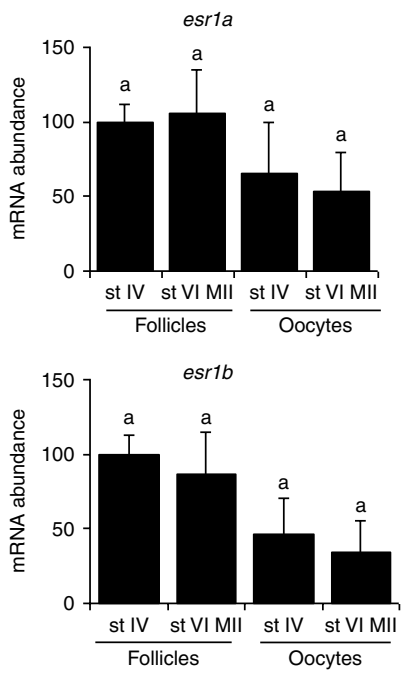

Figure 6 QPCR analysis of estradiol $\left(\mathrm{E}_{2}\right)$ receptor 1 (esr1a and $b$ ) mRNA expression in whole follicles and oocytes during late oogenesis. The mRNA levels of $\mathrm{E}_{2}$ receptor 1 (esr1a and $b$ ) were monitored in whole follicles and denuded oocytes sampled during vitellogenic stage IV (st IV) and matured stage VI (st VI MII). For each sample, three separate RT reactions were carried out using three separate RNA samples originating from three different animals. Analysis of mRNA levels was standardized to levels of $18 S$ rRNA. The mRNA abundance was arbitrarily set to 100 for stage IV follicle. Mean \pm S.E.M. are shown $(n=3)$. No significant difference could be detected (using non-parametric MannWhitney $U$ test). 
(Mulner et al. 1978, Fortune 1983, Gohin et al. 2010). Moreover, Xenopus intra-oocyte $\mathrm{E}_{2}$ concentrations are in the range of $\mathrm{E}_{2}$ content previously measured in the whole follicles (Fortune 1983) and in plasma varying from 1 to $28 \mathrm{ng} / \mathrm{ml}$ corresponding to a maximum of $100 \mathrm{nM}$ (Pickford \& Morris 1999, Hecker et al. 2004, Urbatzka et al. 2007). Moreover, $\mathrm{E}_{2}$ appeared to be maternally inherited as $\mathrm{E}_{2}$ is still detected in Xenopus unfertilized eggs (Kloas 2002). The physiological function of oocyte $\mathrm{E}_{2}$ remains unclear, particularly during oocyte maturation. As reported in Rana pipiens (Schuetz 1972, Spiegel et al. 1978 , Lin \& Schuetz 1983, 1985), $\mathrm{E}_{2}$ appeared to inhibit Xenopus follicle-enclosed oocyte maturation likely through an inhibition of gonadotropin/cAMP-induced progestin synthesis by follicular layers (Lin et al. 1988). However, a direct inhibitory effect of $\mathrm{E}_{2}$ on the oocyte could not be ruled out, as demonstrated in previous studies in Xenopus (Baulieu et al. 1978) and in Rana pipiens (Lin \& Schuetz 1983). Moreover, several studies reported a slight significant effect of high $\mathrm{E}_{2}$ dose pretreatment on Xenopus denuded oocyte maturation (Hanocq-Quertier \& Baltus 1981, Pickford \& Morris 1999). In our study, $\mathrm{E}_{2}$, added simultaneously and at nearly a tenfold oocyte physiological concentration, did not inhibit steroid-triggered maturation in denuded oocytes, suggesting that $\mathrm{E}_{2}$ inhibitory effects are occurring in follicular cells. We even surprisingly observed that $\mathrm{E}_{2}$ exerted a slight enhancing action on progesterone-induced meiotic resumption, especially when used in combination with a sub-saturating dose of the MIS. The potentiating effect of $E_{2}$ evidenced previously and in this study may be due to $\mathrm{E}_{2}$ antioxidant effect.

The effect previously observed after $\mathrm{E}_{2}$ pretreatment may also suggest that its potentiating effect results from a classical genomic mechanism of gene expression activation by ligand-dependent activation of the classical - intracellular - Esr1 and/or Esr2. This is strengthened by the fact that esrl ( $a$ and $b$ ) mRNAs are also detected in Xenopus oocytes and their content remains stable throughout late vitellogenesis and maturation. Nevertheless, $\mathrm{E}_{2}$ may also act through a non-genomic mechanism after activation by ERs of signaling pathways (via c-Src or MAPK pathways) that would subsequently interact with the maturationpromoting factor induction. Indeed, it has been shown in other cell types that ER $\alpha$ (Esr1) directly interacts with and activates Src (Fox et al. 2009), the latter being able to accelerate progesterone-induced oocyte maturation (Tokmakov et al. 2005). Moreover, MAPK activation has been shown to participate in maturation promoting factor (MPF) activation and thus to stimulate Xenopus oocyte maturation (Palmer \& Nebreda 2000). Finally, a modulator of non-genomic action of the ER, MNAR, is also expressed in Xenopus oocytes (Haas et al. 2005). All these results suggest that $\mathrm{E}_{2}$ genomic and non-genomic effects likely play important and unsuspected roles at the oocyte level during late oogenesis that will need to be further characterized.

\section{Declaration of interest}

The authors declare that there is no conflict of interest that could be perceived as prejudicing the impartiality of the research reported.

\section{Funding}

This work was funded by ANR-08-GENM-033 (OSCILE) grant to J B and F C, M G was supported by a doctoral fellowship from CNRS \& Region Bretagne.

\section{Acknowledgements}

The authors thank CNRS personnel (Rennes) for animal care and Stephane Dreano for his technical support in cDNA sequencing.

\section{References}

Ahn RS, Yoo MS \& Kwon HB 1999 Evidence for two-cell model of steroidogenesis in four species of amphibian. Journal of Experimental Zoology 284 91-99. (doi:10.1002/(SICI) 1097-010X (19990615)284:1 < 91::AID-JEZ12>3.0.CO;2-F)

Baulieu EE, Godeau F, Schorderet M \& Schorderetslatkine S 1978 Steroid-induced meiotic division in Xenopus laevis oocytes - surface and calcium. Nature 275 593-598. (doi:10.1038/275593a0)

Bobe J, Montfort J, Nguyen T \& Fostier A 2006 Identification of new participants in the rainbow trout (Oncorhynchus mykiss) oocyte maturation and ovulation processes using cDNA microarrays. Reproductive Biology and Endocrinology 4 39. (doi:10.1186/14777827-4-39)

Chatterton RT Jr, Geiger AS, Khan SA, Helenowski IB, Jovanovic BD \& Gann PH 2004 Variation in estradiol, estradiol precursors, and estrogen-related products in nipple aspirate fluid from normal premenopausal women. Cancer Epidemiology, Biomarkers and Prevention 13 928-935.

Dumont JN 1972 Oogenesis in Xenopus laevis (Daudin). I. Stages of oocyte development in laboratory maintained animals. Journal of Morphology 136 153-179. (doi:10.1002/jmor.1051360203)

Fortune JE 1983 Steroid production by Xenopus ovarian follicles at different developmental stages. Developmental Biology 99 502-509. (doi:10.1016/0012-1606(83)90299-3)

Fostier A, Billard R, Breton B, Legendre M \& Marlot S 1982 Plasma 11-oxotestosterone and gonadotropin during the beginning of spermiation in rainbow trout (Salmo gairdneri R.). General and Comparative Endocrinology 46 428-434. (doi:10.1016/0016$6480(82) 90096-\mathrm{X})$

Fouchet C, Serres C, Belle R \& Ozon R 1975 Mechanism of action of progesterone on amphibian oocytes. Uptake and metabolism of progesterone by isolated oocytes of Pleurodeles waltlii and Xenopus laevis. Comparative Biochemistry and Physiology. B, Comparative Biochemistry 52 205-210. (doi:10.1016/0305-0491(75)90053-X)

Fox EM, Andrade J \& Shupnik MA 2009 Novel actions of estrogen to promote proliferation: integration of cytoplasmic and nuclear pathways. Steroids 74 622-627. (doi:10.1016/j.steroids.2008.10.014) 
Gohin M, Bobe J \& Chesnel F 2010 Comparative transcriptomic analysis of follicle-enclosed oocyte maturational and developmental competence acquisition in two non-mammalian vertebrates. $B M C$ Genomics 11 18. (doi:10.1186/1471-2164-11-18)

Gohin M, Bodinier P, Fostier A, Chesnel F \& Bobe J 2011 Aromatase is expressed and active in the rainbow trout oocyte during final oocyte maturation. Molecular Reproduction and Development 78 510-518. (doi:10.1002/mrd.21335)

Gore-Langton RE \& Dorrington JH 1981 FSH induction of aromatase in cultured rat granulosa cells measured by a radiometric assay. Molecular and Cellular Endocrinology 22 135-151. (doi:10.1016/03037207(81)90087-3)

Gore-Langton R \& Amstrong DT 1988 Follicular steroidogenesis and its control. In The Physiology of Reproduction, pp 331-385. Eds E Knobil \& JD Neill. New York: Raven Press.

Haas D, White SN, Lutz LB, Rasar M \& Hammes SR 2005 The modulator of nongenomic actions of the estrogen receptor (MNAR) regulates transcription-independent androgen receptormediated signaling: evidence that MNAR participates in $\mathrm{G}$ proteinregulated meiosis in Xenopus laevis oocytes. Molecular Endocrinology 19 2035-2046. (doi:10.1210/me.2004-0531)

Hanocq-Quertier J \& Baltus E 1981 Induction of meiosis of Xenopus laevis oocytes by mianserine. Gamete Research 4 49-56. (doi:10.1002/ mrd.1120040108)

Hecker M, Giesy JP, Jones PD, Jooste AM, Carr JA, Solomon KR, Smith EE, Van der Kraak G, Kendall RJ \& Du Preez L 2004 Plasma sex steroid concentrations and gonadal aromatase activities in African clawed frogs (Xenopus laevis) from South Africa. Environmental Toxicology and Chemistry 23 1996-2007. (doi:10.1897/03-450)

Iwabuchi J, Wako S, Tanaka T, Ishikawa A, Yoshida Y \& Miyata S 2007 Analysis of the $\mathrm{p} 450$ aromatase gene expression in the Xenopus brain and gonad. Journal of Steroid Biochemistry and Molecular Biology 107 149-155. (doi:10.1016/j.jsbmb.2007.01.007)

Jalabert B, Fostier A, Marcuzzi O \& Heydorff M 1984 The modulatory effect of oestradiol-17 $\beta$, testosterone or cortisol on the output of $17 \alpha$-hydroxy-20 $\beta$-dihydroprogesterone by rainbow trout (Salmo gairdneri) ovarian follicles stimulated by the maturational gonadotropin s-GtH. Reproduction Nutrition Development 24 127-136. (doi:10.1051/rnd:19840204)

Kamangar BB, Gabillard J-C \& Bobe J 2006 Insulin-like growth factor-binding protein (IGFBP)-1, -2, $-3,-4,-5$, and -6 and IGFBP-related protein 1 during rainbow trout postvitellogenesis and oocyte maturation: molecular characterization, expression profiles, and hormonal regulation. Endocrinology 147 2399-2410. (doi:10.1210/en.2005-1570)

Kato T, Matsui K, Takase M, Kobayashi M \& Nakamura M 2004 Expression of $\mathrm{P} 450$ aromatase protein in developing and in sex-reversed gonads of the XX/XY type of the frog Rana rugosa. General and Comparative Endocrinology 137 227-236. (doi:10.1016/j.ygcen.2004.03.013)

Kloas W 2002 Amphibians as a model for the study of endocrine disruptors. International Review of Cytology 216 1-57. (doi:10.1016/ S0074-7696(02) 16002-5)

Kusakabe M, Todo T, McQuillan HJ, Goetz FW \& Young G 2002 Characterization and expression of steroidogenic acute regulatory protein and MLN64 cDNAs in trout. Endocrinology 143 2062-2070. (doi:10.1210/en.143.6.2062)

Kwon HB \& Ahn RS 1994 Relative roles of theca and granulosa cells in ovarian follicular steroidogenesis in the amphibian, Rana nigromaculata. General and Comparative Endocrinology 94 207-214. (doi:10. 1006/gcen.1994.1077)

LaMarca MJ, Westphal LM \& Rein DA 1985 Gonadotropins and the timing of progesterone-induced meiotic maturation of Xenopus laevis oocytes. Developmental Biology 109 32-40. (doi:10.1016/00121606(85) 90343-4)

Lin YW \& Schuetz AW 1983 In vitro estrogen modulation of pituitary and progesterone-induced oocyte maturation in Rana pipiens. Journal of Experimental Zoology 226 281-291. (doi:10.1002/jez. 1402260214)
Lin YW \& Schuetz AW 1985 Intrafollicular action of estrogen in regulating pituitary-induced ovarian progesterone synthesis and oocyte maturation in Rana pipiens: temporal relationship and locus of action. General and Comparative Endocrinology 58 421-435. (doi:10. 1016/0016-6480(85)90115-7)

Lin YW, Kwon HB, Petrino TR \& Schuetz AW 1988 Studies on the mechanism of action of estradiol in regulating follicular progesterone levels: effects on cAMP mediated events and 3Bhydroxysteroid dehydrogenase. Development, Growth and Differentiation 30 611-618. (doi:10.1111/j.1440-169X. 1988.00611.x)

Monod G, Demones A \& Fostier A 1993 Inhibition of ovarian microsomal aromatase and follicular estradiol secretion by imidazole fungicides in rainbow-trout. Marine Environmental Research 35 153-157. (doi:10.1016/0141-1136(93) 90030-4)

Mourot B, Nguyen T, Fostier A \& Bobe J 2006 Two unrelated putative membrane-bound progestin receptors, progesterone membrane receptor component 1 (PGMRC1) and membrane progestin receptor $(\mathrm{mPR})$ beta, are expressed in the rainbow trout oocyte and exhibit similar ovarian expression patterns. Reproductive Biology and Endocrinology 4 6. (doi:10.1186/1477-7827-4-6)

Mulner O, Thibier C \& Ozon R 1978 Steroid biosynthesis by ovarian follicles of Xenopus laevis in vitro during oogenesis. General and Comparative Endocrinology 34 287-295. (doi:10.1016/0016$6480(78) 90250-2)$

Nagahama Y, Yoshikuni M, Yamashita M, Tokumoto T \& Katsu Y 1995 Regulation of oocyte growth and maturation in fish. Current Topics in Developmental Biology 30 103-145. (doi:10.1016/S00702153(08)60565-7)

Ogawa A, Dake J, Iwashina YK \& Tokumoto T 2011 Induction of ovulation in Xenopus without hCG injection: the effect of adding steroids into the aquatic environment. Reproductive Biology and Endocrinology 9 11. (doi:10.1186/1477-7827-9-11)

Palmer A \& Nebreda AR 2000 The activation of MAP kinase and p34cdc2/cyclin B during the meiotic maturation of Xenopus oocytes. Progress in Cell Cycle Research 4 131-143.

Park JW, Tompsett A, Zhang X, Newsted JL, Jones PD, Au D, Kong R, Wu RS, Giesy JP \& Hecker M 2008 Fluorescence in situ hybridization techniques (FISH) to detect changes in CYP19a gene expression of Japanese medaka (Oryzias latipes). Toxicology and Applied Pharmacology 232 226-235. (doi:10.1016/j.taap.2008. 06.012)

Pickford DB \& Morris ID 1999 Effects of endocrine-disrupting contaminants on amphibian oogenesis: methoxychlor inhibits progesterone-induced maturation of Xenopus laevis oocytes in vitro. Environmental Health Perspectives 107 285-292. (doi:10.1289/ehp. 99107285)

Rasar MA \& Hammes SR 2006 The physiology of the Xenopus laevis ovary. Methods in Molecular Biology 322 17-30. (doi:10.1007/978-159745-000-3_2)

Reynhout JK \& Smith LD 1973 Evidence for steroid metabolism during the in vitro induction of maturation in oocytes of Rana pipiens. Developmental Biology 30 392-402. (doi:10.1016/00121606(73)90096-1)

Rupp RA, Snider L \& Weintraub H 1994 Xenopus embryos regulate the nuclear localization of XMyoD. Genes and Development 8 1311-1323. (doi:10.1101/gad.8.11.1311)

Sanyal MK, Sibre ER \& Greep RO 1973 Breakdown of germinal vesicle of frog oocytes with 5 alpha-reduced products of progesterone in vitro. Proceedings of the Society for Experimental Biology and Medicine $144483-486$.

Schuetz AW 1972 Estrogens and ovarian follicular functions in Rana pipiens. General and Comparative Endocrinology 18 32-36. (doi:10. 1016/0016-6480(72)90076-7)

Spiegel J, Jones E \& Snyder BW 1978 Estradiol-17 beta interference with meiotic maturation in Rana pipiens ovarian follicles: 
evidence for inhibition of 3 beta-hydroxysteroid dehydrogenase. Journal of Experimental Zoology 204 187-191. (doi:10.1002/jez. 1402040207)

Sretarugsa P \& Wallace RA 1997 The developing Xenopus oocyte specifies the type of gonadotropin-stimulated steroidogenesis performed by its associated follicle cells. Development, Growth and Differentiation 39 87-97. (doi:10.1046/j.1440-169X. 1997.00009.x)

Thibier-Fouchet C, Mulner O \& Ozon R 1976 Progesterone biosynthesis and metabolism by ovarian follicles and isolated oocytes Xenopus laevis. Biology of Reproduction 14 317-326. (doi:10. 1095/biolreprod14.3.317)

Tokmakov A, Iwasaki T, Itakura S, Sato K, Shirouzu M, Fukami Y \& Yokoyama S 2005 Regulation of Src kinase activity during Xenopus oocyte maturation. Developmental Biology 278 289-300. (doi:10.1016/ j.ydbio.2004.10.018)

Turner DL \& Weintraub H 1994 Expression of achaete-scute homolog 3 in Xenopus embryos converts ectodermal cells to a neural fate. Genes and Development 8 1434-1447. (doi:10.1101/gad.8.12. 1434)
Urbatzka R, Bottero S, Mandich A, Lutz I \& Kloas W 2007 Endocrine disrupters with (anti) estrogenic and (anti)androgenic modes of action affecting reproductive biology of Xenopus laevis: I. Effects on sex steroid levels and biomarker expression. Comparative Biochemistry and Physiology. Toxicology and Pharmacology 144 310-318. (doi:10. 1016/j.cbpc.2006.10.008)

Vizziano D, Randuineau G, Baron D, Cauty C \& Guiguen Y 2007 Characterization of early molecular sex differentiation in rainbow trout, Oncorhynchus mykiss. Developmental Dynamics 236 2198-2206. (doi:10.1002/dvdy.21212)

Yang WH, Lutz LB \& Hammes SR 2003 Xenopus laevis ovarian CYP17 is a highly potent enzyme expressed exclusively in oocytes. Evidence that oocytes play a critical role in Xenopus ovarian androgen production. Journal of Biological Chemistry 278 9552-9559. (doi:10.1074/jbc.M212027200)

Received in final form 8 July 2011

Accepted 18 July 2011

Made available online as an Accepted Preprint 18 July 2011 